\title{
Effects of the Water-Based Foaming Process on the Basic and Rheological Properties of Bitumen 70/100
}

\author{
Marek Iwański *iD, Anna Chomicz-Kowalska, Grzegorz Mazurek, Przemysław Buczyński (D), \\ Małgorzata Cholewińska, Mateusz M. Iwański (D), Krzysztof Maciejewski (D) and Piotr Ramiączek
}

\section{check for}

updates

Citation: Iwański, M.

Chomicz-Kowalska, A.; Mazurek, G.;

Buczyński, P.; Cholewińska, M.;

Iwański, M.M.; Maciejewski, K.;

Ramiączek, P. Effects of the

Water-Based Foaming Process on the Basic and Rheological Properties of Bitumen 70/100. Materials 2021, 14, 2803. https://doi.org/10.3390/

ma14112803

Academic Editor: Giovanni Polacco

Received: 2 May 2021

Accepted: 21 May 2021

Published: 25 May 2021

Publisher's Note: MDPI stays neutral with regard to jurisdictional claims in published maps and institutional affiliations.

Copyright: (c) 2021 by the authors. Licensee MDPI, Basel, Switzerland. This article is an open access article distributed under the terms and conditions of the Creative Commons Attribution (CC BY) license (https:// creativecommons.org/licenses/by/ $4.0 /)$.
Department of Civil Engineering and Architecture, Kielce University of Technology, Al. Tysiąclecia Państwa Polskiego 7, 25-314 Kielce, Poland; a.kowalska@tu.kielce.pl (A.C.-K.); gmazurek@tu.kielce.pl (G.M.); p.buczynski@tu.kielce.pl (P.B.); m.cholewinska@tu.kielce.pl (M.C.); matiwanski@tu.kielce.pl (M.M.I.); kmaciejewski@tu.kielce.pl (K.M.); piotrr@tu.kielce.pl (P.R.)

* Correspondence: miwanski@tu.kielce.pl

\begin{abstract}
The process of water-based foaming of bitumen produces binders that can be incorporated in cold recycled asphalt mixes and pavement upper structural layers made of half-warm mix asphalt prepared at $100-130{ }^{\circ} \mathrm{C}$. During the foaming process, cold water and air act on hot bitumen $\left(160-170{ }^{\circ} \mathrm{C}\right)$, which results in the explosive vaporization of water leading to changes in the binder structure. The impact of foaming on the properties of bitumen $70 / 100$ was evaluated by investigating the binder characteristics before and after foaming. Determination of two foaming parameters, maximum expansion and half-life, was followed by measurements of penetration at $25^{\circ} \mathrm{C}$, softening point, Fraass breaking point, and dynamic viscosity at 60,90 , and $135^{\circ} \mathrm{C}$. Rheological and low-temperature tests were also performed before and after foaming bitumen 70/100. The Bending Beam Rheometer method was applied to determine the low temperature stiffness modulus. A DHR-2 rheometer was used to determine the dynamic modulus and phase angle of the tested binder. The Black and master curves before and after foaming were plotted in the 2S2P1D model and the model parameters were analysed. Analysis of the test results confirmed the effects of the foaming process on the basic, low-temperature, and rheological characteristics of the bitumen.
\end{abstract}

Keywords: water-foamed bitumen; fundamental properties; rheology; low-temperature properties; 2S2P1D model

\section{Introduction}

Dynamic development of water-foamed bitumen technology started at the turn of the 21st century with the research led by prof. K. J. Jenkins in South Africa [1]. Initially, the technology was used for cold deep recycling of asphalt pavements [2,3]. With groundwork laid, the interest in water foaming of bitumen spread across borders [4-8]. Researchers looked at how various modifiers affect the properties of bitumen after foaming $[9,10]$ and evaluated the impact of different minerals, including waste materials, on the properties of recycled asphalt mixtures [11,12].

Sustainable technologies aimed at emission reductions have contributed to the development of asphalt mixtures produced at temperatures of about $120-140{ }^{\circ} \mathrm{C}$. Traditional hot mixes are produced at about $170^{\circ} \mathrm{C}$, depending on the type of bitumen used $[13,14]$. With the emergence of Warm Mix Asphalt (WMA) technologies [15-17], water-foamed bitumen was found to be applicable to mixtures used in pavement upper layers [18,19]. Further development allowed lowering mix production temperatures even more, to about 90-110 ${ }^{\circ} \mathrm{C}$ (Half Warm Mix Asphalt, HWMA) [20-22]. At the same time, to ensure high quality of the HWMA material, researchers looked at the influence of various chemical compounds on the binder basic parameters, i.e., maximum expansion (ER) and half-life (HL) $[9,23]$, and properties of foamed bitumen mixtures [24-26]. 
Compared with conventional technology, low production temperature of HWMA and WMA with and without foamed bitumen alleviates the negative impact of high temperature on the bitumen [12,13], reduces the rate of its ageing [27-29], and generates smaller changes in binder parameters and mixture properties [30-32]

Foamed bitumen binder is produced by subjecting the bitumen to the effect of pressurized water injected together with air. Rapid vaporization of water in the bitumen forms the bitumen foam [1,4,24]. Water and air affect the internal structure of the binder by initiating processes that change its properties after the foam decays and the bitumen regains its original consistency. Here, bitumen ageing is not due to temperature but rather to the action of pressurized water vapour and oxygen contained in the air. Due to the specificity of the foaming process and the fact that bitumen foam is primarily used in recycled base layers, this issue has not yet been widely investigated.

Alterations of bitumen chemical composition and morphology due to ageing can be successfully observed using Atomic Force Microscopy (AFM) [33,34] and ATR spectroscopy. Such changes were demonstrated in the study reported by Iwański et al. [30]. Their findings were consistent with the test results presented by Dong et al. [35].

Bitumen ageing in conventional mixtures is not as important as in HWMA and WMA intended for pavement upper layers $[13,14,30,36,37]$. The use of foamed bitumen reduces the short-term ageing process to a very short period during its injection into the mineral mix at $<100{ }^{\circ} \mathrm{C}$. More frequent use of bituminous mixtures in the upper layers, in particular in the wearing course, makes it necessary to identify the effects of the bitumen foaming process on the standard and rheological characteristics of the binder.

\section{Materials and Research Methodology}

\subsection{Tested Materials}

Bitumen 70/100 used in this work was produced at ORLEN S.A refinery in Płock. This bitumen grade is commonly used in the Central and Eastern European countries for cold recycled bases in pavements under traffic loads of $2.5 \times 10^{6}<\mathrm{ESAL}_{100 \mathrm{kN}}<$ $7.3 \times 10^{6}$ (ESAL-equivalent single axle load) [38]. Table 1 compiles the basic properties of this binder.

Table 1. Basic properties of 70/100 bitumen.

\begin{tabular}{cccc}
\hline Property & Test Method & Unit of Measure & Result \\
\hline Penetration at $25^{\circ} \mathrm{C}$ & EN 1426 [39] & $0.1 \mathrm{~mm}$ & 70 \\
Softening point $T_{R \& B}$ & EN 1427 [40] & ${ }^{\circ} \mathrm{C}$ & 47 \\
Fraass breaking point & EN 12593 [41] & ${ }^{\circ} \mathrm{C}$ & -18 \\
Dynamic viscosity at: & & & 154 \\
$60^{\circ} \mathrm{C}$ & EN 13302:2011 [42] & Pa.s & 27 \\
$90^{\circ} \mathrm{C}$ & & & 0.9 \\
$135^{\circ} \mathrm{C}$ & & & \\
\hline
\end{tabular}

Proper preparation of binder samples is critical for the quality of the test and uniformity of the results. The samples were shipped in $5 \mathrm{~L}$ containers directly from the refinery and then transferred to 1L steel cans in accordance with EN 12594 [43]. In the next step, the samples were pre-heated to the softening point of the binder plus $100{ }^{\circ} \mathrm{C}$ and stirred at the rate of $150 \mathrm{rpm}$ for $30 \mathrm{~s}$, and then $600 \mathrm{rpm}$ for $270 \mathrm{~s}$. The $250 \mathrm{~g}$ test samples were placed in the heated vacuum chamber to remove air bubbles. The quality of the test samples was assessed through macroscopic examination.

\subsection{Experimental Program}

Tests on bitumen $70 / 100$ before and after foaming involved three stages. First, the foaming parameters were evaluated. Then the basic, rheological and low-temperature properties of the binder, as well as the effect of foaming on these properties were determined. 
Basic parameters of bitumen foam are used to determine the optimal amount of foaming water. Optimization result is typically the relationship between the amount of water used and two foaming parameters: $E R_{m}(-)$ and HL (s). The Technical Guidelines [5] describe the test methodology in detail. Since the measurement accuracy can be affected by the researcher, a laser-based method was used to measure bitumen foam changes over time.

An original digital measuring device was developed at the Kielce University of Technology [44] to increase the accuracy of the results. The device was designed based on literature data $[45,46]$ pointing to a strong dependence of the measurement results on the researcher's experience.

The device employs a highly accurate laser sensor, similar to that used by Newcomb et al. [47]. The non-contact measurement of displacement was based on the principle of optical triangulation. A laser diode illuminates a point on the surface to be measured. The light reflected from this point is directed to the photosensitive matrix, where it is processed in real time. The declared accuracy of the distance measurement for the $50 \mathrm{~mm}$ range is $\pm 15 \mu \mathrm{m}$. A photo of the device and digital recorder, as well as the schematic diagram of the device are shown in Figure 1.

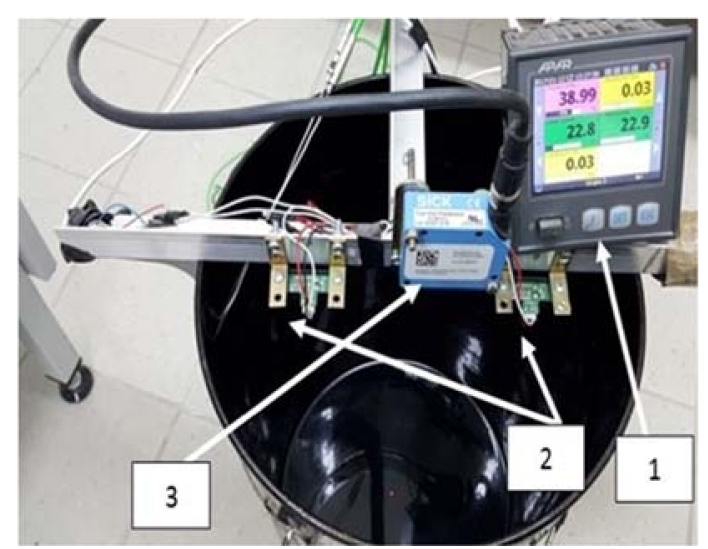

(a)

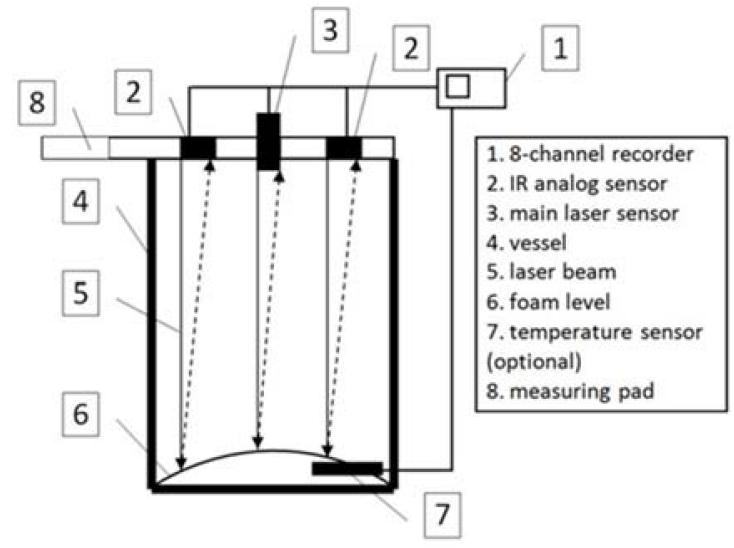

(b)

Figure 1. Design of the original measuring pad for measuring bitumen foaming parameters (1—recorder, 2—analog IR sensors of distance measurement, 3-laser sensor): (a) photograph of the device; (b) schematic diagram [44].

The binder was foamed at $160^{\circ} \mathrm{C}, 6.0 \mathrm{kPa}$ water pressure and $5.5 \mathrm{kPa}$ air pressure, with the foaming water content of $2.5 \%$ by weight of the binder. The bitumen foam was taken directly from the foaming nozzle into glass containers and left to cool to room temperature. In order to prepare test specimens, the foamed binder was reheated as per EN 12594 [43] requirements.

The foaming characteristics quantified during the first stage of the study included:

- maximum expansion ratio, $E R_{m}[1,5]$,

- $\quad$ half-life, HL $[1,5]$,

- $\quad$ foam index, $F I[1]$.

As recommended by Jenkins [1], the quality of the foamed bitumen was assessed using the foam index $(F I)$, which is measured in seconds and calculated using the following formula:

$$
F I=\frac{-\mathrm{HL}}{\ln 2} \cdot\left(4-E R_{m}-4 \ln \cdot\left(\frac{4}{E R_{m}}\right)\right)+\left(\frac{1+C}{2 C}\right) \cdot E R_{m} \cdot t_{s}(s)
$$

where:

$C$ - correction factor (ratio of measured and actual $E R, E R_{\mathrm{m}} / E R_{\mathrm{a}}$ ),

$H L$ - half-life (s),

$t_{s}$-discharge time (s), 
$E R_{m}$-measured expansion ratio (immediately after foaming),

$E R_{a}$-actual expansion ratio.

Physical properties of the foam were evaluated at the Foaming Water Content (FWC) of $1.5 \%, 2.0 \%, 2.5 \%, 3.0 \%, 3.5 \%$, and $4.0 \%$ in the WLB-10S laboratory plant. The test conditions [5] were as follows:

- temperature of bitumen: $155^{\circ} \mathrm{C}$,

- temperature of water: $20^{\circ} \mathrm{C}$,

- water flow: $100 \mathrm{~g} / \mathrm{s}$,

- foaming time: $5 \mathrm{~s}$,

- $\quad$ air pressure: $500 \mathrm{kPa}$,

- $\quad$ water pressure: $600 \mathrm{kPa}$.

Optimum values of ER and HL were determined using a mathematical formula that represents the relationship between the foaming parameters and the water content. The optimum FWC should ensure the highest expansion and the longest half-life.

The second stage of the testing program involved determining the pre and post foaming basic properties of the bitumen:

- penetration at $25^{\circ} \mathrm{C}$ (Pen, EN 1426:2015-08) [39], which is a measure of bitumen consistency,

- $\quad$ softening point ( $T_{R \mathcal{E B}}, \mathrm{EN}$ 1427:2015-08) [40],

- Fraass breaking point ( $T_{\text {Fraass }}, \mathrm{EN}$ 12593:2015-08) [41],

- dynamic viscosity at $60{ }^{\circ} \mathrm{C}, 90^{\circ} \mathrm{C}$, and $135^{\circ} \mathrm{C}$ (EN 13302-2018) [42].

The temperature range of binder plasticity $(P R)$, which depends on its softening point $\left(T_{R \mathcal{} B}\right)$ and breaking point $\left(T_{\text {Fraass }}\right)$, was determined from:

$$
P R=T_{R \& B}-T_{\text {Fraass }}\left({ }^{\circ} \mathrm{C}\right)
$$

In the final stage, the rheological and low-temperature properties of the binder before and after foaming were determined through:

- $\quad$ rheological tests: dynamic modulus, dynamic viscosity, and phase angle at temperatures $13^{\circ} \mathrm{C}, 25^{\circ} \mathrm{C}$, and $40^{\circ} \mathrm{C}$ and loading time $(0.1-10 \mathrm{~Hz})$ to EN 14770 [48], and

- low-temperature tests to EN 14771 [49].

- The binders before BBR testing were adequately subjected to short-term ageing in the rolling thin-film oven (RTFOT, 2011, Matest, Treviolo, Italy).

The rheological tests for linear viscoelasticity of bitumen 70/100 were performed before and after foaming using a DHR-2 dynamic shear rheometer ((Discovery Hybrid Rheometer, 2019, TA Instruments, New Castle, DE, USA) shown in Figure 2.

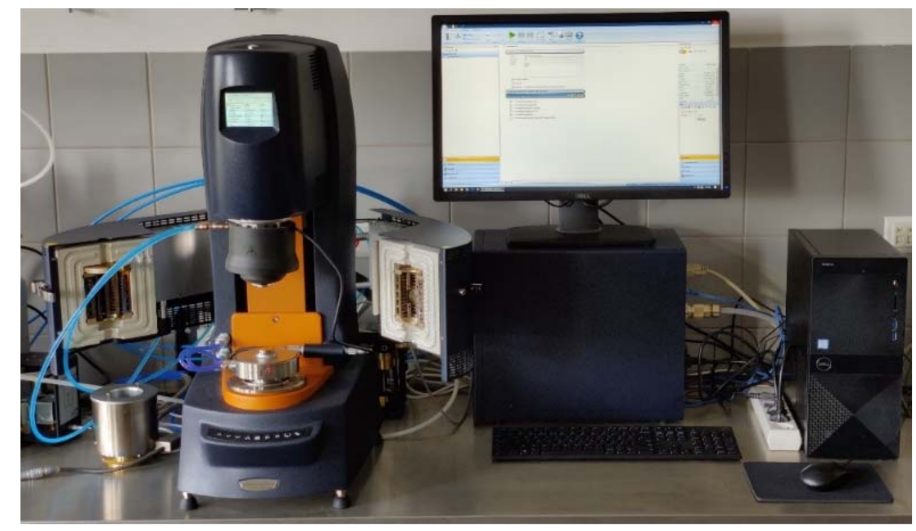

Figure 2. Discovery Hybrid Rheometer DHR-2.

The linear viscoelasticity region was determined according to the SHRP-A-370 report [50]. The maximum strain amplitude of the dynamic modulus $\left|G^{*}\right|$ for temperatures 
$+13,25,40$, and $60{ }^{\circ} \mathrm{C}$ was set at $0.1 \%$, which corresponds to a stress of $<50 \mathrm{~Pa}$. The purpose of testing the dynamic modulus at different temperatures was to construct a master curve model based on the Time Temperature Superposition Principle (TTSP). The modified HuetSayegh model (2S2P1D) [51] was used. The same model had previously been applied by the authors to assess the rheology of the bitumen recovered from pavement layers [52].

Another important step in investigating bitumen rheology was the evaluation of low temperature stiffness of bitumen samples using the Bending Beam Rheometer (BBR2S Bending Beam Rheometer, Applied Test Systems, Butler, PA, USA) method was used [44,53]. The testing setup used is shown in Figure 3.

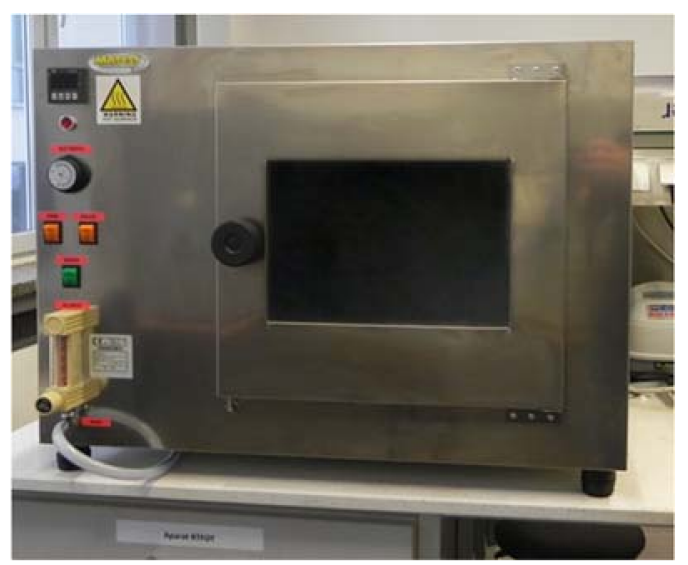

(a)

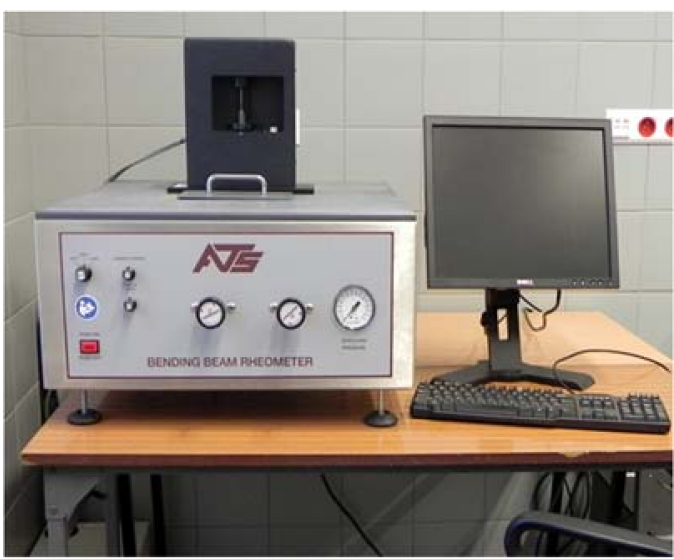

(b)

Figure 3. Test setup for determining low-temperature stiffness modulus of bitumen; RTFOT (a), BBR (b).

Analysis of the bitumen low temperature response allowed the evaluation of low temperature relaxation modulus corresponding to the instantaneous stiffness modulus.

\section{Results}

\subsection{Properties of Water-Foamed Bitumen 70/100}

The suitability of bitumen 70/100 for foaming was assessed in accordance with the methodology used by the authors of [54]. The optimum amount of water was determined in accordance with the guidelines [5]. Nine determinations of the given foaming parameter were made. The results are shown in Figure 4.

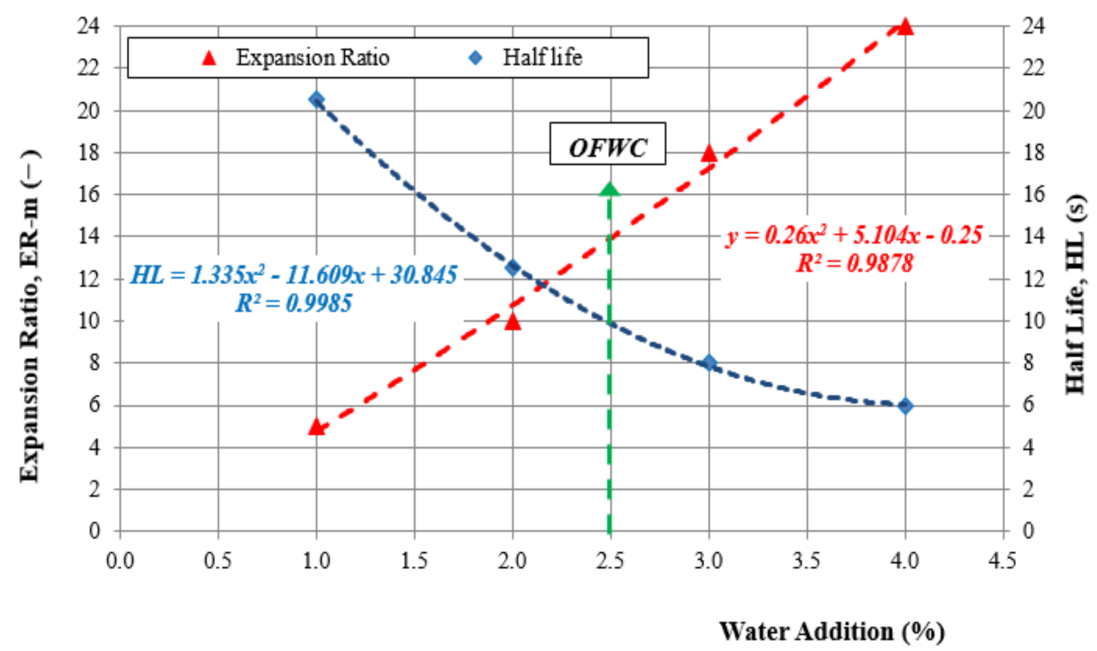

Figure 4. Optimum water content for foaming bitumen 70/100. 
The relationship between $E R_{m}$ and HL was the basis for determining the optimum FWC $=2 \%$ by weight of the binder for which $E R_{m}=12$ and $H L=12 \mathrm{~s}$ and $F I=122$.

\subsection{Basic Properties of Bitumen}

The present study aimed to evaluate the influence of the foaming process on the basic properties of bitumen $70 / 100$. The plan of the experiment included determining penetration at $25^{\circ} \mathrm{C}$ (Pen) as per EN 1426 [39] (10 replicates), the softening point by the "ring and ball" method ( $\left.T_{P i K}\right)$ as per EN 1427 [40] (6 replicates), and the Fraass breaking point ( $T_{\text {Fraass }}$ ) as per EN 12593 [41] (4 replicates) before and after foaming. Table 2 shows the mean results of the penetration, softening point and breaking point determinations. Since the analysis was to evaluate the effect of the foaming process on these parameters, the results in individual series were designated as $70 / 100$ for the non-foamed binder and as F 70/100 for the foamed binder.

Table 2. Determined properties of bitumen binder $70 / 100$ before and after foaming.

\begin{tabular}{ccccccc}
\hline \multirow{2}{*}{ Binder Type } & \multicolumn{2}{c}{ Pen $(\mathbf{0 . 1} \mathbf{~ m m})$} & \multicolumn{2}{c}{$T_{\text {REB }}\left({ }^{\circ} \mathbf{C}\right)$} & \multicolumn{2}{c}{$T_{\text {Fraass }}\left({ }^{\circ} \mathbf{C}\right)$} \\
\cline { 2 - 7 } & Mean & SD & Mean & SD & Mean & SD \\
\hline $70 / 100$ & 70.2 & 2.346 & 46.8 & 0.085 & -17.8 & 0.957 \\
\hline F 70/100 & 68.0 & 3.690 & 46.3 & 0.230 & -17.5 & 0.577 \\
\hline
\end{tabular}

C the softening point of $46.8^{\circ} \mathrm{C}$ and the breaking point of $-17.8^{\circ} \mathrm{C}$, and met the requirements of EN 12591 in the above range. It follows from the mean values that after foaming the penetration value decreased by an average of $2.2(0.1 \mathrm{~mm})$, the softening point decreased by $0.5^{\circ} \mathrm{C}$, and the breaking point increased by $0.3^{\circ} \mathrm{C}$. Standard deviation for penetration and softening point also increased after foaming.

The statistical significance of the foaming process for the bitumen 70/100 basic properties was assessed using a one-way analysis of variance ANOVA, the results of which are presented in Table $3[55,56]$.

Table 3. One-way analysis of variance. Significance of foaming effect (independent variable: Binder) on the properties of bitumen 70/100: Pen, $T_{P i K}, T_{\text {Fraass }}$.

\begin{tabular}{ccc}
\hline variable: & Repeatability Error & $p(\alpha=0.05)$ \\
$P e n$ & 9.600 & 0.105 \\
Binder & Repeatability & $p(\alpha=0.05)$ \\
variable: & 0.030 & $<0.001$ \\
$T_{R \& B}$ & Repeatability & $p(\alpha=0.05)$ \\
Binder & 0.625 & 0.670 \\
\hline variable: & & \\
$T_{\text {Frasss }}$ & &
\end{tabular}

The results of statistical analysis showed a significant influence of foaming on the softening point. The changes in penetration and breaking point values were not significant.

Figure 5 shows the mean values of the basic properties of bitumen 70/100 before and after foaming, together with standard deviation. The data in Figure 5 confirm the ANOVA results in that the influence of the foaming process on the values of penetration and breaking point is not statistically significant. Despite the demonstrated statistical significance of foaming for the softening point, the difference between its values before and after foaming is marginal. 


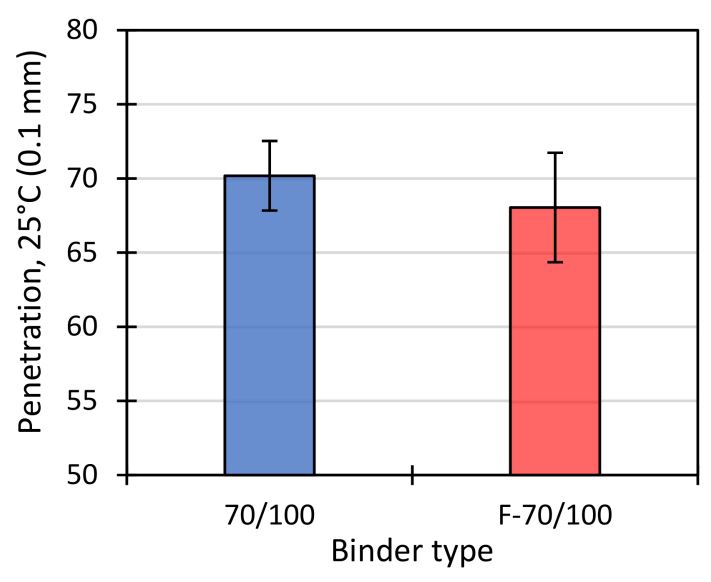

(a)

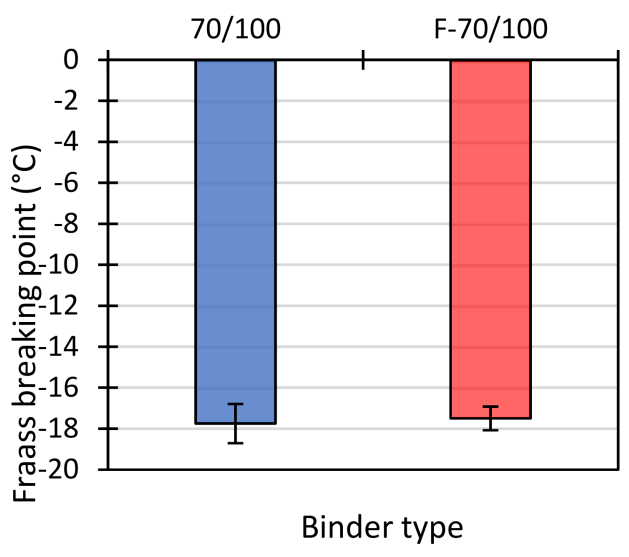

(c)

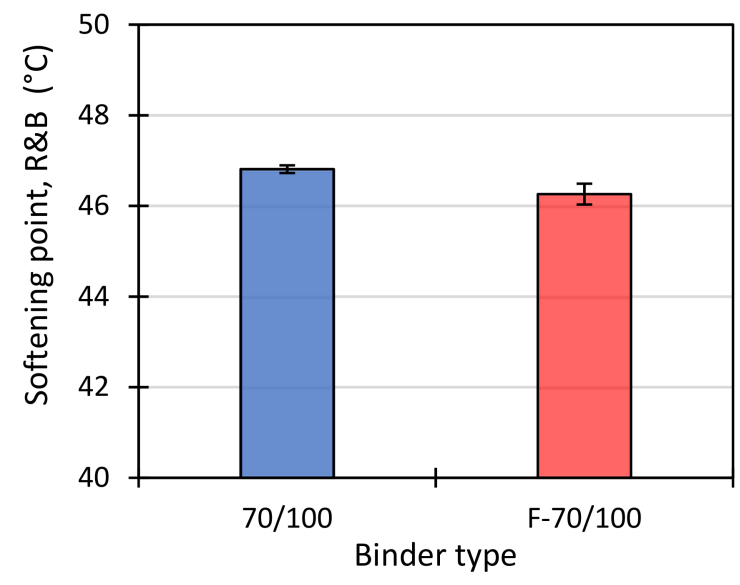

(b)

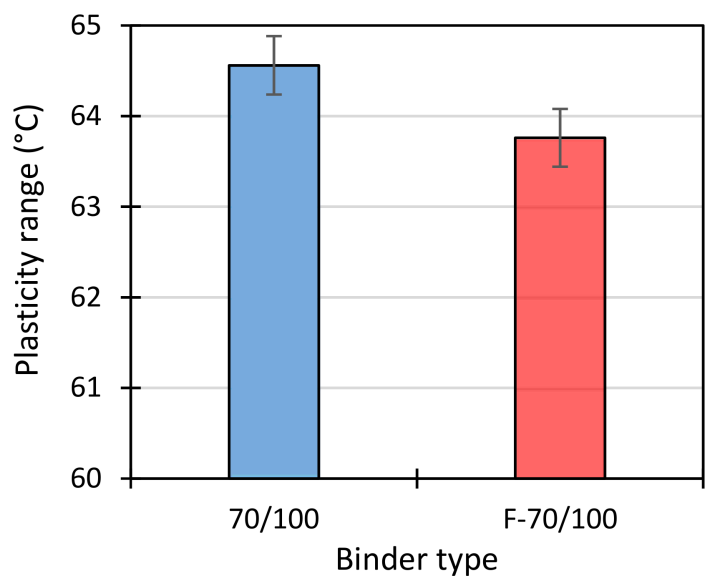

(d)

Figure 5. Properties of bitumen $70 / 100$ before and after foaming: penetration at $25^{\circ} \mathrm{C}$ (a); softening point (b); Fraass breaking point (c), plasticity range (d); error bars represent standard deviation.

The test results for the basic properties of bitumen $70 / 100$ (penetration at $25{ }^{\circ} \mathrm{C}$, softening point (ring and ball) and breaking point) before and after foaming allow the following conclusions:

- non-foamed binder 70/100 meets the requirements set forth in EN 12591; after foaming, the penetration value of the binder was lower $(68.0(0.1 \mathrm{~mm})$; $\mathrm{min}=70.0(0.1 \mathrm{~mm}))$;

- the foaming process had a statistically significant effect only on the softening point, which dropped from 46.8 to $46.3^{\circ} \mathrm{C}$;

- foaming had non-significant impact on penetration and Fraass breaking point,

- $\quad$ the plasticity range of the binder after foaming decreased slightly (from 64.6 to 63.7) as a result of a decrease in the softening point and a slight increase in the Fraass breaking point.

Dynamic viscosity changes were compared as a function of temperature. The tests were performed at four temperatures: $60,90,135$ and $150{ }^{\circ} \mathrm{C}$. The dynamic viscosity test was performed at a constant rotational speed of $\mathrm{s}^{-1}$. Three bitumen samples were tested. The range of the results did not exceed 5\% [42]. Viscosity variations were determined by fitting the objective function, which was the Arrhenius-Guzman equation [57] in the form:

$$
\eta=A \cdot e^{\left(\frac{B}{T}\right)}
$$

where:

$A, B$-material constants of the fluid, 
T-temperature, ${ }^{\circ} \mathrm{C}$,

$\eta$-dynamic viscosity, Pas.

Figure 6 shows the fitting result and the plot of the function.

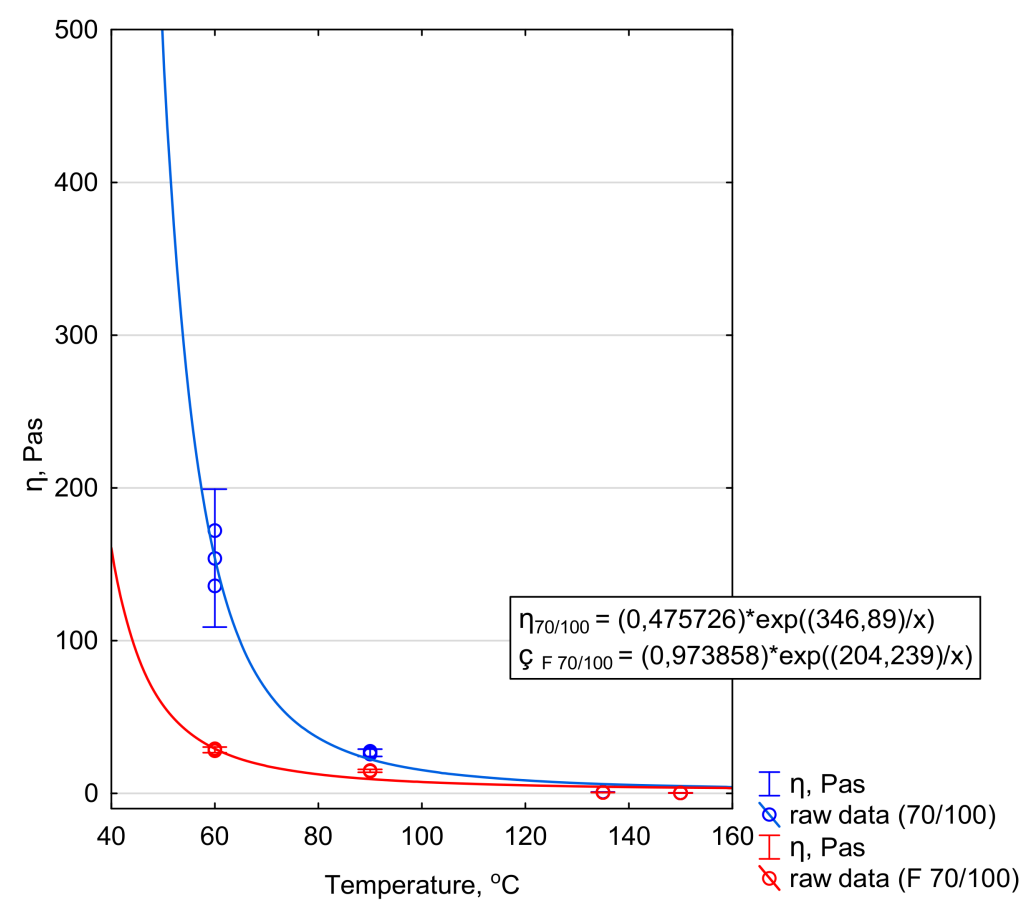

Figure 6. Dynamic viscosity of bitumen 70/100 and bitumen F 70/100 (after foaming). Error bars demonstrate the confidence interval.

From the data in Figure 6 it follows that the largest difference between dynamic viscosities of $70 / 100$ and $\mathrm{F} 70 / 100$ occurred at the temperature lower than $100{ }^{\circ} \mathrm{C}$. The rapid drop in the value of dynamic viscosity of bitumen F 70/100 was related to its more porous nature. The air bubbles remaining after the foaming process disturbed the structure of bitumen F 70/100 at the lower temperature. The dynamic viscosity fell due to the presence of dispersed air spheres. The variation of coefficient $B$ in model (3) confirms this observation. The $B$ coefficient is directly related to the viscous flow activation energy. It expresses the molar energy necessary to overcome the intermolecular forces that inhibit the sliding of the layers with fluid flow. Thus, the low value of factor B of bitumen F 70/100 compared with $70 / 100$ explains the rapid decrease in dynamic viscosity. At temperature higher than $100{ }^{\circ} \mathrm{C}$, the viscosity of bitumen $\mathrm{F} 70 / 100$ was low enough to eliminate the impact of air voids on dynamic viscosity which reached a similar level for both bitumen types.

\subsection{Rheological and Low-Temperature Tests}

Rheological tests were performed on the reference bitumen before foaming (70/100) and after foaming (F-70/100). Bitumen F-70/100 was tested at the half-life (HL) of 180-240 min.

The low temperature stiffness modulus is an important indicator used for the assessment of bitumen rheology.

Analysis of bitumen low temperature behaviour included an estimation of the low temperature relaxation modulus corresponding to the instantaneous stiffness modulus.

The following rheological tests of the reference bitumen (70/100) and foamed bitumen (F 70/100) were performed:

- $\quad$ BBR stiffness modulus in accordance with EN 14771 [49],

- dynamic modulus test $\left|\mathrm{G}^{*}\right|$ at temperatures $+13,25,40$, and $60^{\circ} \mathrm{C}$ and the frequency range of 0.1 to $10 \mathrm{~Hz}$ in accordance with EN 14770 [48]. 
Four measurements were made at each of the test temperatures $(-16,-20,-25$, and $-30^{\circ} \mathrm{C}$ ) [53]. A graphical presentation of the results is given in Figure 7.

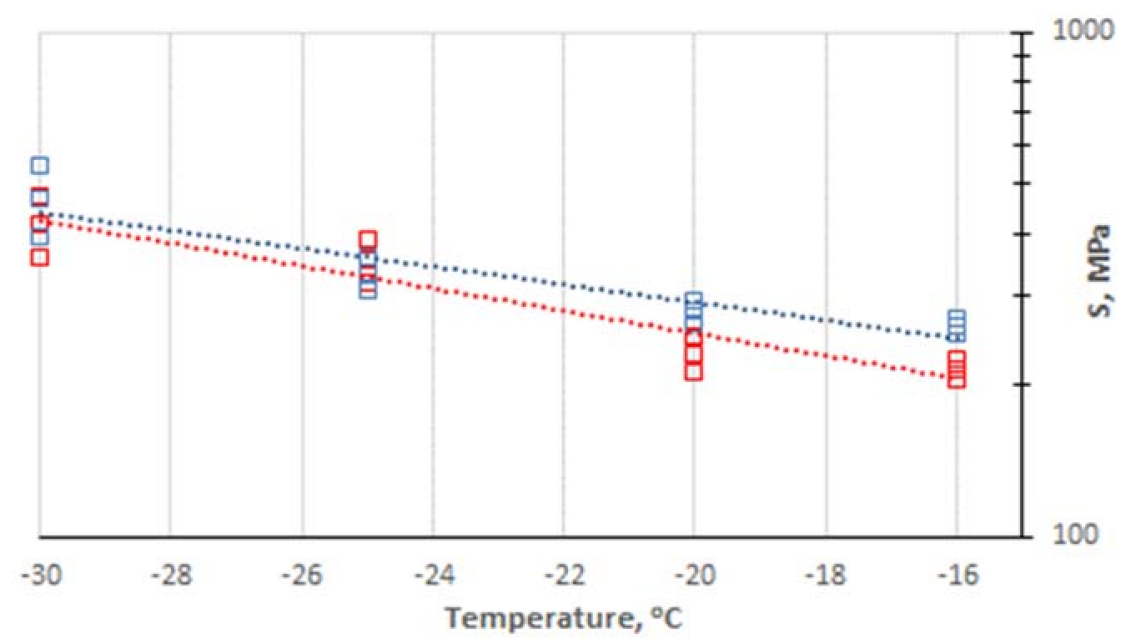

口F $70 / 100$

(a)

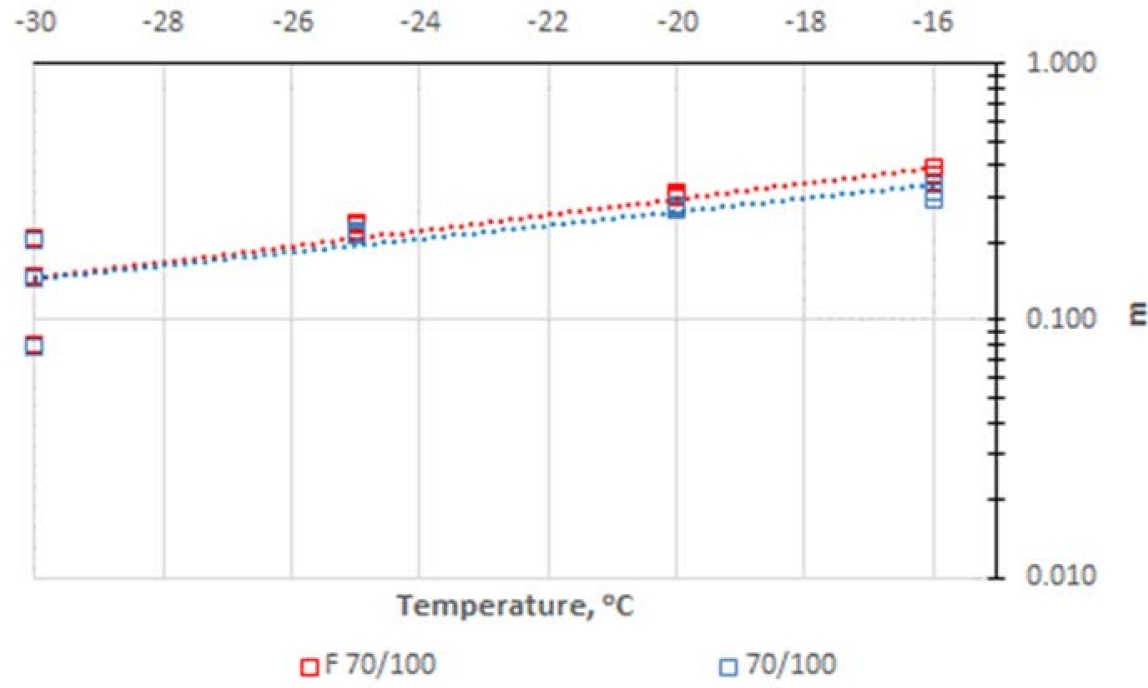

(b)

Figure 7. Creep parameter change at low temperature (BBR); (a) stiffness at $60 \mathrm{~s}$, (b) coefficient $\mathrm{m}$.

The low-temperature properties assessment was based on parameters $S(60)$ and $m(60)$ obtained from three replications of the samples prepared separately for each temperature [49]. Parameter S(60) represents the temperature at which the bitumen sample reached the value of $300 \mathrm{MPa}$. The accompanying parameter $\mathrm{m}(60)$ represents a slope of the curve. The highest temperature value from the $S(60)$ and $\mathrm{m}(60)$ determination is the critical temperature of the binder. Table 4 summarizes the values of low-temperature properties. 
Table 4. Stiffness modulus S, parameter $\mathrm{m}$, and critical temperature.

\begin{tabular}{|c|c|c|c|}
\hline Bitumen & $\begin{array}{c}\mathrm{S}(60)=300(\mathrm{MPa}) \\
\mathrm{T}(\mathrm{S}) 60\left({ }^{\circ} \mathrm{C}\right)\end{array}$ & $\begin{array}{c}\mathrm{m}(60)=0.3 \\
\mathrm{~T}(\mathrm{~m}) 60\left({ }^{\circ} \mathrm{C}\right)\end{array}$ & $\mathrm{S}(\mathrm{T})_{-16}(\mathrm{MPa})$ \\
\hline $70 / 100$ & -19.2 & -17.9 & 262 \\
\hline F 70/100 & -21.3 & -19.8 & 215 \\
\hline
\end{tabular}

Since the critical temperature in the case of bitumen F 70/100 $\left(-19.8^{\circ} \mathrm{C}\right)$ is lower than that of the reference binder $\left(-17.9^{\circ} \mathrm{C}\right)$, and the stress measured at $-16^{\circ} \mathrm{C}$ as per EN 14023 [58] is also lower, the use of F 70/100 in a cold-recycled mix ensures its increased and beneficial compliance at low temperatures. Maintaining the increased flexibility in the low temperature range is likely to minimize the occurrence of low temperature cracking in the structural layers made of recycled mixtures. This phenomenon has the greatest impact on mix rheology at low temperatures. Bitumen F 70/100 will thus have a beneficial effect on the relaxation rate of thermally induced stresses [57].

Bitumen 70/100 was subjected to a series of rheological tests for linear viscoelasticity before and after foaming using a dynamic shear rheometer. Dynamic tests were performed to determine the characteristic master curves, which were in fact a relaxation function model. As it is not possible to determine the dynamic modulus using one measuring system, the tests were performed for one frequency range at several temperature levels. Using the superposition principle [51,59], master curves were constructed (2S2P1D model) for both bitumen types. The BBR tests aimed to determine the bitumen maximum stiffness at the load approaching zero (high frequency). The value estimated for the solution region $<1 \mathrm{~Pa}$ was adopted as the value of the bitumen dynamic modulus as time tends to infinity. The model consists of two springs:

- $\mathrm{G}_{\infty}$ (equivalent of the static modulus/the loading time tends to infinity),

- $\mathrm{G}_{0}$ (instantaneous modulus/the loading time tends to zero),

- two parabolic dashpots: $h$ and $k$,

- $\quad$ a linear dashpot $\beta$ (defined by zero shear viscosity $\eta_{0}$ ),

- $\quad t$-loading time,

- $\quad h$-exponent changing from 0 to 1 ( $h=0$ elastic behaviour, $h=1$ viscous behaviour).

After the transformation of the 2S2P1D model in the frequency domain, the function describing time-dependent variation in $\left|G^{*}\right|$ has the form:

$$
\mathrm{G}^{*}(\omega)=\mathrm{G}_{0}+\frac{\mathrm{G}_{\mathrm{g}}-\mathrm{G}_{0}}{1+\alpha(\mathrm{i} \omega \tau)^{-\mathrm{k}}+(\mathrm{i} \omega \tau)^{-\mathrm{h}}+\alpha(\mathrm{i} \omega \beta \tau)^{-1}}
$$

where:

$\mathrm{G}^{*}(\omega)$-dynamic modulus in the frequency domain,

$\mathrm{k}$ and $\mathrm{h}$-exponents $0<\mathrm{k}<\mathrm{h}<1 \mathrm{~h}$ changing from 0 to 1 ( $\mathrm{h}=0$ elastic response, $\mathrm{h}=1$ viscous response),

$\alpha, \beta$-constants,

$\tau$-characteristic time,

Using the relationship below:

$$
\eta_{0}=\left(G_{g}-G_{0}\right) \beta \tau
$$

where $\eta_{0}$-zero shear viscosity, it is possible to determine dynamic viscosity for long-term loading. As it has an influence on the increase in plastic deformation rate in asphalt concrete, this parameter can be helpful in determining asphalt mixture susceptibility to permanent deformation (rutting).

The estimation of the model parameters required the use of the nonlinear least squares method to minimize the objective function at established initial values. A complex block 
script was prepared in MathCad using a solver with the implemented quasi-Newton method [60].

In order to estimate the seven parameters of the model, at least eight determinations of the dynamic modulus $\left|G^{*}\right|$ at different frequencies are required. The mechanical parameters of the 2S2P1D model are independent of temperature, unlike those in the widely used Burger model. The characteristic time can only be described by temperature, which is the correct solution when the time-temperature superposition principle (TTSP) is used in the model. This allows building master curves to describe changes in complex modulus values with time. The TTSP was determined from the modified equation:

$$
\tau=\tau_{0} \mathrm{e}^{\left(\mathrm{A}_{0}+\mathrm{T} \cdot \mathrm{A}_{1}\right)}
$$

where:

T-test temperature,

$\tau_{0}$-initial characteristic time,

$\mathrm{A}_{0}, \mathrm{~A}_{1}$ - parameters of the model.

This method of defining the time-temperature superposition (6) is characterized by a compromise between the quality of parameter estimation and the number of its parameters. The last step in the approximation of 2S2P1D model parameters is assessing the fit of the model to the values obtained. Two qualitative measures were used: the coefficient of determination $\mathrm{R}^{2}$ and the mean normalized error, MNE [61,62]. Since these measures are not correlated, the high quality of the model must rely on high $\mathrm{R}^{2}$ and low MNE.

Model parameter estimation was based on the value of the dynamic modulus $\left|G^{*}\right|$ and the phase angle $\delta$. The overall results are presented using the Black chart. Figure 8 compares the rheological nature of the bitumens before and after foaming.

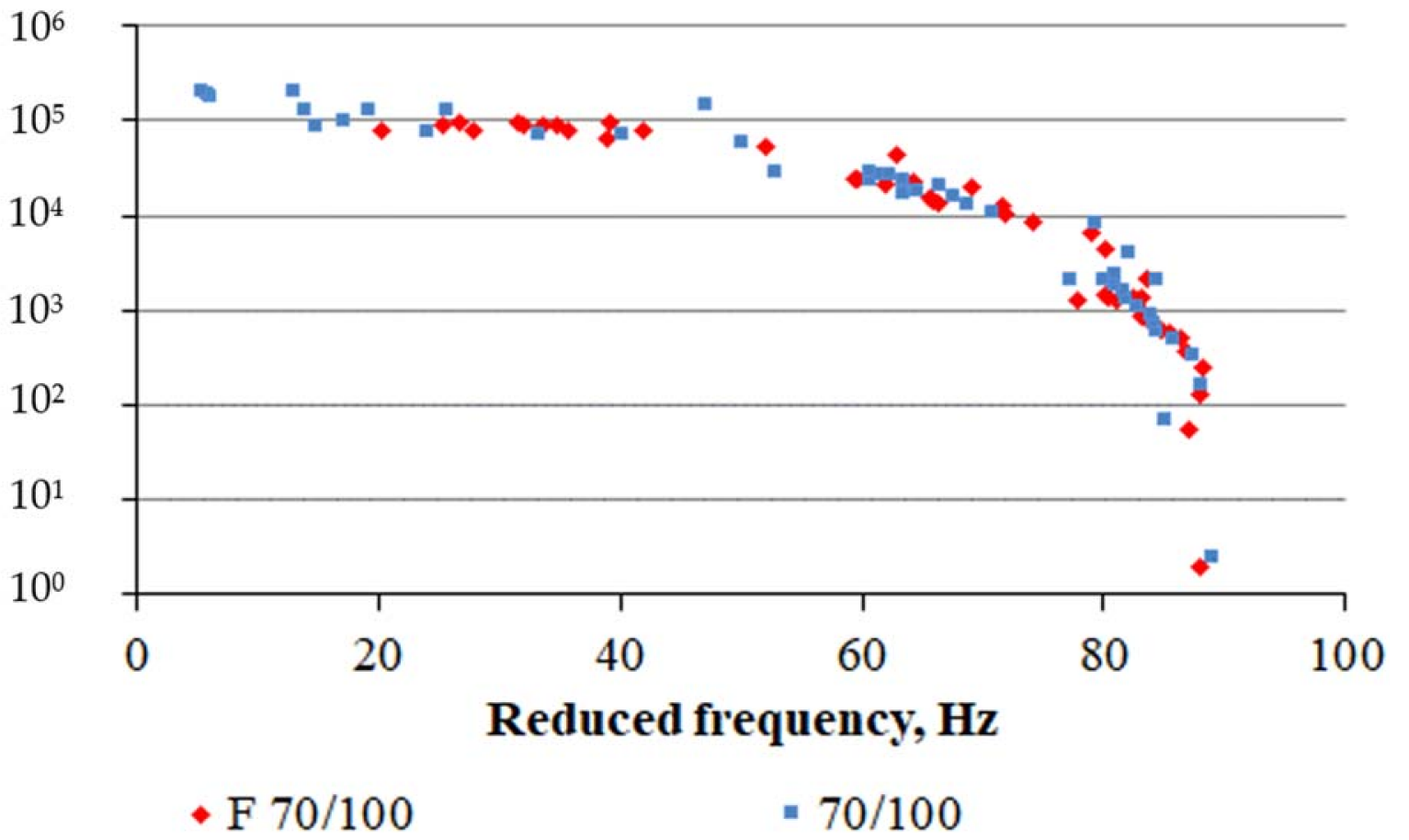

Figure 8. Black curve for bitumen 70/100 before and after foaming.

Analysis of the results in Figure 8 shows that the foaming process changed the rheological character of the binder. Reference bitumen 70/100 had much higher stiffness in the temperature range of $25^{\circ} \mathrm{C}$, as indicated by the small phase angle results. The phase angle values for bitumen $\mathrm{F} 70 / 100$ are shifted to the range of higher values, which suggests that the viscous component $G^{\prime \prime}$ of the dynamic modulus $\left|G^{*}\right|$ will dominate in this bitumen. 
As a result, the bitumen will be more susceptible to the creep effect. However, when used as a dispersed phase in a cement-based mixture, it will reduce the stiffness caused by the presence of the hydraulic binder. In the range of high phase angles, the difference between the foamed bitumen F 70/100 and the reference bitumen 70/100 was negligible. The rheological nature of both bitumens was compared by plotting master curves for $40{ }^{\circ} \mathrm{C}$ using the 2S2P1D model, as shown in Figure 9.

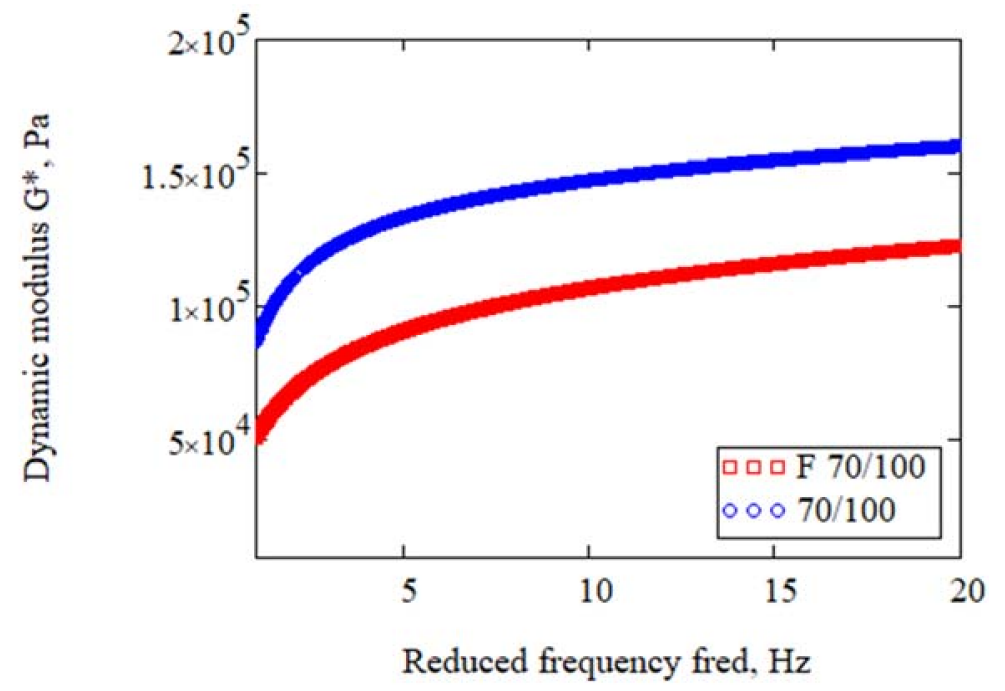

Figure 9. Master curves of bitumen $70 / 100$ and bitumen $\mathrm{F} 70 / 100$ at $40{ }^{\circ} \mathrm{C}$ based on the 2S2P1D model.

The plot of the master curve at $40^{\circ} \mathrm{C}$ (Figure 9) indicates that compared with F 70/100, the reference bitumen $(70 / 100)$ obtains higher values of the dynamic modulus $\left|G^{*}\right|$ and thus higher stiffness over the entire frequency range. Also, the shape of the 70/100 master curve suggests that the bitumen reaches its elastic state much faster. Interpretation of the master curve was based on the comparison of its parameters, which are not temperaturedependent. The 2S2P1D model parameters for the reference and foamed bitumens are tabulated in Table 5 .

Table 5. 2S2P1D model parameters for the bitumen (70/100, F 70/100) under analysis.

\begin{tabular}{|c|c|c|c|c|c|c|c|c|c|}
\hline \multirow[b]{2}{*}{ Bitumen } & \multicolumn{9}{|c|}{ 2S2P1D Model Parameters } \\
\hline & $\begin{array}{c}\delta \\
(-)\end{array}$ & $\begin{array}{l}k \\
(-)\end{array}$ & $\begin{array}{l}\text { h } \\
(-)\end{array}$ & $\begin{array}{c}\beta / \eta_{0} \\
(-) / \text { Pas }\end{array}$ & $\begin{array}{c}\mathrm{G}_{\mathbf{o}} / \mathrm{G}_{\infty} \\
(\mathbf{P a})\end{array}$ & $\begin{array}{c}\tau \\
(\mathrm{s})\end{array}$ & $\begin{array}{c}A_{0} / A_{1} \\
(-)\end{array}$ & $\begin{array}{l}R^{2} \\
(-)\end{array}$ & $\begin{array}{c}\text { RMSE } \\
(\%)\end{array}$ \\
\hline F 70/100 & 1.7 & 0.13 & 0.26 & $172.3 / 1 \times 10^{7}$ & $3.5210^{-5} / 8.93 \times 10^{5}$ & 0.065 & $-0.201 / 2.5 \times 10^{-3}$ & 0.97 & 9.2 \\
\hline $70 / 100$ & 2.01 & 0.28 & 0.56 & $12.6 / 2.97 \times 10^{7}$ & $0.027 / 2.37 \times 10^{6}$ & 0.1 & $-0.22 / 0.158$ & 0.99 & 14.0 \\
\hline
\end{tabular}

Analysis of the 2S2P1D model (Table 5) shows that the phase angle $\delta$ for the reference bitumen is higher than for the foamed binder. Its value suggests a higher level of $\left|G^{*}\right|$ in the reference bitumen as confirmed by the plot of the master curve in Figure 9. The zero shear viscosity $\eta_{0}$ for bitumen $70 / 100$ is nearly twice as high as that of $F 70 / 100$. This indicates lower resistance of F 70/100 to permanent deformation, which is related to the amount of air bubbles trapped in the bitumen phase contributing to the viscous character of the binder. Sensitivity of the binder to the effects of a long-term loading is also indicated by the $h$ factor, which for F 70/100 is twice that of the reference bitumen. In fact, the deformation of foamed bitumen under long-term loads will occur nearly twice as fast as in the reference bitumen. Parameters $h$ and $k$ describe the slope of the curve in the Cole-Cole diagram (Figure 10). 


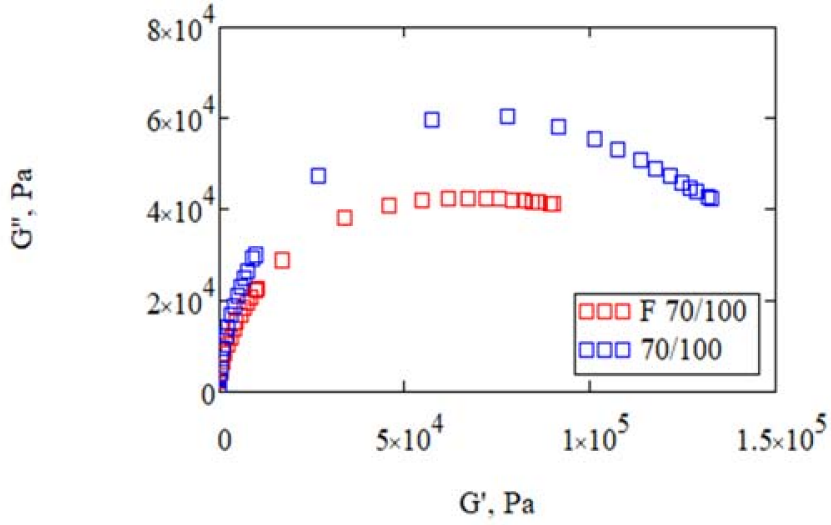

(a)

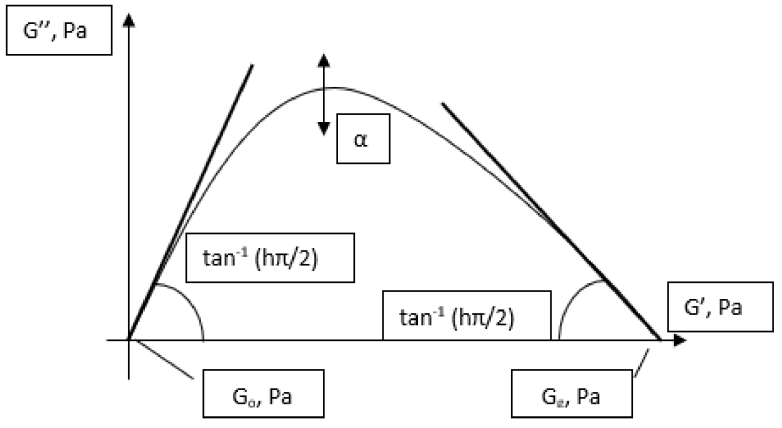

(b)

Figure 10. Cole-Cole plot: (a) results of bitumen 70/100 before and after foaming; (b) graphical representation of the 2S2P1D model.

Each of the parameters of the 2S2P1D model plays a specific role in shaping the Cole-Cole plot (Figure 10b):

- $\quad k$ controlled the slope at high values of $\mathrm{G}^{\prime \prime}$ in the Cole-Cole diagram,

- $\quad h$ controlled the slope at low values of $G^{\prime \prime}$ in the Cole-Cole diagram,

- $\delta$ controlled the slope at the low temperatures/high frequencies in the $\left|G^{*}\right|$ master curve and the height of the pinnacle point of the Cole-Cole diagram,

- $\quad \beta$ controlled the slope at the high temperatures/low frequencies of the $\left|G^{*}\right|$ master curve. It is also correlated with the zero shear viscosity $\eta_{0}$.

The master curve projected on the $G^{\prime}-G^{\prime \prime}$ plane (Figure 10a) shows that $70 / 100$ is markedly stiffer compared to $\mathrm{F} 70 / 100$. Also, the $\mathrm{k}$ value for the reference bitumen $(\mathrm{k}=0.13)$ is approximately $30 \%$ higher than that of the foamed bitumen $(\mathrm{k}=0.1)$. Accordingly, the $\mathrm{h}$ parameter representing the bitumen viscous nature is lower in F 70/100 than in 70/100. This demonstrates that the reference bitumen $(70 / 100)$ will have a more elastic character than bitumen F 70/100. It must be emphasized that the presence of entrapped air reduced zero shear viscosity $\eta_{0}$ in F70/100, which suggests that the mixture will show higher susceptibility under long-term loading.

Nevertheless, the dominance of $G^{\prime \prime}$ over $G^{\prime}$ will probably improve the fatigue life of the asphalt mixture with $\mathrm{F} 70 / 100$ compared to that produced with bitumen $70 / 100[63,64]$. The lower value of $\delta=1.7$ of $F 70 / 100$ relative to $70 / 100(\delta=2.01)$ suggests a better stress relaxation capability of F 70/100, which is important in terms of fatigue life of the asphalt mixture.

\section{Conclusions}

Foaming has a considerable effect on the basic parameters and rheology of bitumen $70 / 100$, as demonstrated in this study. Conclusions drawn from the tests and observations are as follows:

- Water-foaming changes basic characteristics of bitumen such as penetration at $25^{\circ} \mathrm{C}$, softening point and breaking point. In the case of the softening point, this effect is more pronounced and statistically significant.

- Water-foaming reduced the critical temperature of the bitumen. The stress read at $-16{ }^{\circ} \mathrm{C}$ as per EN 14023 [58] was lower for foamed bitumen F 70/100 than for the reference bitumen $70 / 100$.

- The critical temperature was $-19.8{ }^{\circ} \mathrm{C}$ in $\mathrm{F} 70 / 100$ and $-17.9{ }^{\circ} \mathrm{C}$ in $70 / 100$. Therefore, the application of bitumen $\mathrm{F} 70 / 100$ will ensure that a cold recycled cement-based mixture in which it is incorporated will have improved and more beneficial compliance in the range of low temperatures. 
- The foaming process changed the rheological character of the bitumen under test. The reference bitumen $70 / 100$ exhibited considerably higher stiffness at $25^{\circ} \mathrm{C}$ range, as demonstrated by small values of the phase angle. Higher values of the phase angle for $F 70 / 100$ indicate that the viscous component $G^{\prime \prime}$ of the dynamic modulus $\left|G^{*}\right|$ will dominate. As a result, this bitumen will be more susceptible to creep.

- The plot of the master curve at $40{ }^{\circ} \mathrm{C}$ indicates that, compared with the foamed bitumen, the reference bitumen attains higher values of the dynamic modulus $\left|G^{*}\right|$, hence the higher stiffness over the entire frequency range. The shape of the bitumen $70 / 100$ curve suggests that this bitumen type attains elastic state much faster than F 70/100.

In summary, foaming changes the properties of bitumen and the parameters of cold and warm asphalt mixtures. However, the analysis of foamed bitumen properties and the results of numerous field and laboratory experiments indicate that this change does not affect the main mechanical characteristics of the mixture but contributes to its high quality $[11,21]$.

Author Contributions: Conceptualization, M.I. and G.M.; Data curation, M.M.I.; Formal analysis, P.B. and G.M. Investigation, M.C.; Methodology, M.M.I. and P.B.; Resources, A.C.-K.; Supervision, M.M.I.; Visualization, G.M. and P.R.; Writing—original draft, M.M.I.; Writing—review \& editing, M.M.I. and K.M. All authors have read and agreed to the published version of the manuscript.

Funding: This publication was supported by the program of the Minister of Science and Higher Education under the name: Regional Initiative of Excellence in 2019-2022 project number 025/RID/2018/19 financing amount PLN 12.000.000.

Institutional Review Board Statement: Not applicable.

Informed Consent Statement: Not applicable.

Data Availability Statement: Data available on request from the corresponding author.

Acknowledgments: The research results were developed as part of the project entitled "The innovative technology used the binding agent optimization that provides the long service life of the recycled base course" (TECHMATSTRATEG1/349326/9/NCBR/2017) within the scientific undertaking of Strategic Research and Development Program entitled "Modern Materials Technology" (TECHMATSTRATEG I), which is financed by the National Center for Research and Development (Poland).

Conflicts of Interest: The authors declare no conflict of interest.

\section{References}

1. Jenkins, K.J. Mix Design Considerations for Cold and Half-Warm Bituminous Mixes with Emphasis on Foamed Bitumen. Ph.D. Thesis, Department of Civil Engineering, Faculty of Engineering, University of Stellenbosch, Stellebosch, South Africa, 2000.

2. Muthen, K.M. Foamed asphalt mixes. mix design procedure. In Contract Report CR 98/077; SABITA Ltd\&CSIR Transportek: Pretoria, South Africa, 2009.

3. Iwański, M.; Chomicz-Kowalska, A. Evaluation of the effect of using foamed bitumen and bitumen emulsion in cold recycling technology. In Proceedings of the 3rd International Conference on Transportation Infrastructure (ICTI), Sustainability, EcoEfficiency and Conservation in Transportation Infrastructure Asset Management, Pisa, Italy, 22-25 April 2014; Taylor and Francis: Abington, UK, 2014; Volume 8, pp. 69-76.

4. Saleh, M. Characterization of Foam Bitumen Quality and the Mechanical Properties of Foam Stabilized Mixes; University of Canterbury Research Repository: Christchurch, New Zealand, 2006.

5. Wirtgen. Wirtgen Cold Recycling Technology, 1st ed.; Wirtgen GmbH: Windhagen, Germany, 2012.

6. Mallick, R.B.; Hendrix, G. Use of foamed asphalt in recycling incinerator ash for construction of stabilized base course. Resour. Conserv. Recycl. 2004, 42, 239-248. [CrossRef]

7. Iwański, M.; Cholewińska, M. Application of the foamed bitumen and bitumen emulsion to the road base mixes in the deep cold recycling technology. Balt. J. Road Bridge Eng. 2014, 11, 291-301. [CrossRef]

8. Yan, J.; Ni, F.; Yang, M.; Li, J. An experimental study on fatigue properties of emulsion and foam cold recycled mixes. Constr. Build. Mater. 2010, 24, 2151-2156. [CrossRef]

9. Iwański, M.; Chomicz-Kowalska, A.; Maciejewski, K. Application of synthetic wax for improvement of foamed bitumen parameters. Constr. Build. Mater. 2015, 83, 62-69. [CrossRef] 
10. Iwański, M.M.; Chomicz-Kowalska, A.; Maciejewski, K. Impact of additives on the foamability of a road paving bitumen. IOP Conf. Ser. Mater. Sci. Eng. 2019, 603, 1-10. [CrossRef]

11. Buczyński, P.; Iwański, M. Inactive Mineral filler as a stiffness modulus regulator in foamed bitumen-modified recycled base layers. IOP Conf. Ser. Mater. Sci. Eng. 2017, 245, 1-9. [CrossRef]

12. Mazurek, G.; Iwański, M. Multidimensional analysis of the effects of waste materials on physical and mechanical properties of recycled mixtures with foamed bitumen. Appl. Sci. 2018, 8, 282. [CrossRef]

13. Stefańczyk, B.; Mieczkowski, P. Mieszanki Mineralno-Asfaltowe: Wykonawstwo i Badania. (Bituminous Mixtures: Performance and Research); WKiŁ: Warszawa, Poland, 2008; p. 322. (In Polish)

14. Piłat, J.; Radziszewski, P. Nawierzchnie Asfaltowe: Podręcznik Akademicki. (Asphalt Pavements; Academic Handbook); WKiŁ: Warszawa, Poland, 2010. (In Polish)

15. Pszczola, M.; Jaczewski, M.; Rys, D.; Jaskula, P.; Szydlowski, C. Evaluation of asphalt mixture low-temperature performance in bending beam creep test. Materials 2018, 11, 100. [CrossRef]

16. Leng, Z.; Gamez, A.; Al-Qadi, I.L. Mechanical property characterization of warm-mix asphalt prepared with chemical additives. J. Mater. Civ. Eng. 2014, 26, 304-311. [CrossRef]

17. Cheraghian, G.; Cannone Falchetto, A.; You, Z.; Chen, S.; Kim, Y.S.; Westerhoff, J.; Moon, K.H.; Wistuba, M.P. Warm mix asphalt technology: An up to date review. J. Clean. Prod. 2020, 268, 122128. [CrossRef]

18. Jenkins, K.J.; de Groot, J.L.A.; Van de Ven, M.F.C.; Molenaar, A. Half-warm foamed bitumen treatment, a new process. In Proceedings of the 7th Conference on Asphalt Pavements for Southern Africa, Victoria Falls, Zimbabwe, 29 August2 September 1999.

19. Van De Ven, M.F.C.; Jenkins, K.J.; Voskuilen, J.L.M.; Van De Beemt, R. Development of (half-) warm foamed bitumen mixes: State of the art. Int. J. Pavement Eng. 2007, 8, 163-175. [CrossRef]

20. Chomicz-Kowalska, A.; Gardziejczyk, W.; Iwański, M.M. Analysis of IT-CY stiffness modulus of foamed bitumen asphalt concrete compacted at 95 degrees C. Procedia Eng. 2017, 172, 550-559. [CrossRef]

21. Mrugała, J.; Iwański, M.M. Resistance to permanent deformation of asphalt concrete with F-T wax modified foamed bitumen. Procedia Eng. 2015, 108, 459-466. [CrossRef]

22. Król, J.; Kowalski, K.; Radziszewski, P. Rheological behavior of n-alkane modified bitumen in aspect of Warm Mix Asphalt technology. Constr. Build. Mater. 2015, 93, 703-710. [CrossRef]

23. Yu, X.; Leng, Z.; Wang, Y.; Lin, S. Characterization of the effect of foaming water content on the performance of foamed crumb rubber modified asphalt. Constr. Build. Mater. 2014, 67, 279-284. [CrossRef]

24. Vaiana, R.; Iuele, T.; Gallelli, V.; Tighe, S.L. Warm mix asphalt by water-containing methodology: A laboratory study on workability properties versus micro-foaming time. Can. J. Civ. Eng. 2014, 41, 183-190. [CrossRef]

25. Iwański, M.M. Synergistic Effect of F-T synthetic wax and surface-active agent content on the properties and foaming characteristics of bitumen. Materials 2021, 14, 300. [CrossRef]

26. Yu, X.; Wang, Y.; Luo, T. Impacts of water content on rheological properties and performance-related behaviours of foamed war-mix asphalt. Constr. Build. Mater. 2013, 48, 203-209. [CrossRef]

27. Iwański, M.M.; Chomicz-Kowalska, A.; Maciejewski, K. Resistance to moisture-induced damage of half-warm-mix asphalt concrete with foamed bitumen. Materials 2020, 13, 654. [CrossRef]

28. Hailesilassie, B.W.; Hugener, M.; Partl, M.N. Influence of foaming water content on foam asphalt mixtures. Constr. Build. Mater. 2015, 85, 65-77. [CrossRef]

29. Cholewińska, M.; Iwański, M.; Mazurek, G. The impact of aging on the bitumen stiffness modulus using the CAM Model. Balt. J. Road Bridge Eng. 2018, 13, 34-39. [CrossRef]

30. Iwański, M.; Mazurek, G.; Buczyński, P.; Zapała-Sławeta, J. Multi-dimensional analysis of the foaming process impact on 50/70 bitumen ageing. Constr. Build. Mater. 2020, 266, 1-15. [CrossRef]

31. Dong, F.; Yu, X.; Liang, X.; Ding, G.; Wei, J. Influence of foaming water and aging process on the properties of foamed asphalt. Constr. Build. Mater. 2017, 153, 866-874. [CrossRef]

32. Chomicz-Kowalska, A.; Gardziejczyk, W.; Iwański, M.M. Moisture resistance and compactibility of asphalt concrete produced in half-warm mix asphalt technology with foamed bitumen. Constr. Build. Mater. 2016, 15, 108-118. [CrossRef]

33. Zhang, H.L.; Yu, J.Y.; Feng, Z.G.; Xue, L.H.; Wu, S.P. Effect of Aging on the Morphology of Bitumen by Atomic Force Microscopy: Effect of aging on morphology of bitumen. J. Microsc. 2012, 246, 11-19. [CrossRef]

34. Yu, X.; Burnham, N.A.; Tao, M. Surface microstructure of bitumen characterized by atomic force microscopy. Adv. Interface Sci. 2015, 218, 17-33. [CrossRef]

35. Dong, F.; Yu, X.; Wang, T.; Yin, L.; Li, N.; Si, J.; Li, J. Influence of base asphalt aging levels on the foaming characteristics and rheological properties of foamed asphalt. construction and building materials. Constr. Build. Mater. 2018, 177, 43-50. [CrossRef]

36. Iwański, M.M. Effect of Hydrated Lime on Indirect Tensile Stiffness Modulus of Asphalt Concrete Produced in Half-Warm Mix Technology. Materials 2020, 13, 4731. [CrossRef] [PubMed]

37. General Directorate for National Roads and Motorways. WT-2. Technical Guidelines 2: Asphalt Pavements for National Roads. Part I: Asphaltmixes; General Directorate for National Roads and Motorways: Warsaw, Poland, 2014; p. 48. 
38. Judycki, J.; Jaskuła, P.; Pszczoła, M.; Alenowicz, J.; Dołżycki, B.; Jaczewski, M.; Ryś, D.; Stienss, M. Katalog Typowych Konstrukcji Nawierzchni Podatnych i Pótsztywnych (Catalogue of Typical Flexible and Semi-Rigid Pavement Constructions); GDDKiA: Warsaw, Poland, 2014; p. 112. (In Polish)

39. Comite Europeen de Normalisation. EN 1426:2015-08. Bitumen and Bituminous Binders-Determination of Needle Penetration; Comite Europeen de Normalisation: Brussels, Belgium, 2015.

40. Comite Europeen de Normalisation. EN 1427:2015-08. Bitumen and Bituminous Binders—Determination of Softening Point-Ring and Ball Method; Comite Europeen de Normalisation: Brussels, Belgium, 2015.

41. Comite Europeen de Normalisation. EN 12593:2015-08. Bitumen and Bituminous Binders—Determination of the Fraass Breaking Point; Comite Europeen de Normalisation: Brussels, Belgium, 2015.

42. Comite Europeen de Normalisation. EN 13302-2018. Bitumen and Bituminous Binders-Determination of Dynamic Viscosity of Bituminous Binder Using a Rotating Spindle Apparatus Viscosity of Bituminous Binder Using a Rotating Spindle Apparatus; Comite Europeen de Normalisation: Brussels, Belgium, 2018.

43. Comite Europeen de Normalisation. EN 12594:2014-12. Bitumen and Bituminous Binders_Preparation of Test Samples; Comite Europeen de Normalisation: Brussels, Belgium, 2014.

44. Iwański, M.; Mazurek, G.; Buczyński, P. Bitumen foaming optimisation process on the basis of rheological properties. Materials 2018, 11, 1854. [CrossRef] [PubMed]

45. Martinez-Arguelles, G.; Giustozzi, F.; Crispino, M.; Flintsch, G.W. Investigating physical and rheological properties of foamed bitumen. Constr. Build. Mater. 2014, 72, 423-433. [CrossRef]

46. Saleh, M.F. Effect of rheology on the bitumen foamability and mechanical properties of foam bitumen stabilised mixes. Int. J. Pavement Eng. 2007, 8, 99-110. [CrossRef]

47. Newcomb, D.E.; Arambul, E.; Yin, F.; Zhang, J.; Bhasin, A.; Li, W.; Arega, Z. Properties of Foamed Asphalt for Warm Mix Asphalt Applications; Transportation Research Board: Washington, DC, USA, 2015.

48. Comite Europeen de Normalisation. EN 14770, Bitumen and Bituminous Binders-Determination of Complex Shear Modulus and Phase Angle. Dynamic Shear Rheometer (DSR); Comite Europeen de Normalisation: Brussels, Belgium, 2012.

49. Comite Europeen de Normalisation. EN 14771, Bitumen and Bituminous Binders-Determination of The Flexural Creep StiffnesBending Beam Rheometer (BBR); Comite Europeen de Normalisation: Brussels, Belgium, 2012.

50. Petersen, J.C.; Strategic Highway Research Program (U.S.). Binder Characterization and Evaluation; National Research Council: Washington, DC, USA, 1994.

51. Olard, F.; Di Benedetto, H. General "2S2P1D" model and relation between the linear viscoelastic behaviours of bituminous binders and mixes. Road Mater. Pavement Des. 2003, 4, 185-224.

52. Iwański, M.; Mazurek, G. Applying of 2S2P1D model for assessing viscoelastic properties of bituminous binder extracted from SMA mixture with hydrated lime addition. Cem. Lime Concr. 2018, 23, 124-136.

53. Pilat, J.; Król, J.; Błażejowski, K.; Kowalski, K.; Sarnowski, M. Badania Sztywności Pełzania Asfaltów w Reometrze Zginanej Belki $(B B R)^{\prime \prime}$. (Research on the Creep Stiffness of Bitumen in the Beam Bending Rheometer (BBR)), Drogownictwo (Road Construction); Stowarzyszenie Inżynierów i Techników Komunikacji Rzeczpospolitej Polskiej: Warsaw, Poland, 2010; pp. 75-80.

54. Piasta, Z.; Lenarcik, A. Methods of statistical multi-criteria optimization. In Optimization Methods for Material Design of Cement-based Composites; CRC Press: Boca Raton, FL, USA, 1998; pp. 45-59.

55. Koronacki, J.; Mielniczuk, J. Statystyka dla Studentów Kierunków Technicznych i Przyrodniczych. (Statistics for Technical and Natural Sciences Students); Wydawnictwa Naukowo-Techniczne: Warszawa, Poland, 2004. (In Polish)

56. Iwański, M.; Mazurek, G. The effect of hydrated lime on the rheological properties of extracted bitumen from stone mastic asphalt. Cem. Lime Concr. 2014, 2014, 378-383.

57. Yusoff, N.I. Modelling the Linear Viscoelastic Rheological Properties of Bituminous Binders; University of Nottingham: Nottingham, $\mathrm{UK}, 2012$.

58. Comite Europeen de Normalisation. EN 14023:2011, Bitumen qnd Bituminous Binders. Specification Framework for Polymer Modified Bitumens; Comite Europeen de Normalisation: Brussels, Belgium, 2011.

59. Schramm, G. Reologia: Podstawy i Zastosowania, (Rheology: Fundamentals and applications); Ośrodek Wydawnictw Naukowych PAN: Poznan, Poland, 1998.

60. Benker, H. Practical Use of Mathcad®: Solving Mathematical Problems with a Computer Algebra System; Springer: London, UK, 1999.

61. Montgomery, D.C. Design and Analysis of Experiments, 8th ed.; John Wiley \& Sons, Inc.: Hoboken, NJ, USA, 2013.

62. Yusoff, N.I.; Mounier, D.; Marc-Stéphane, G.; Rosli Hainin, M.; Airey, G.D.; Di Benedetto, H. Modelling the rheological properties of bituminous binders using the 2S2P1D Model. Constr. Build. Mater. 2013, 38, 395-406. [CrossRef]

63. Kim, Y.R. Modeling of Asphalt Concrete; ASCE Press: Reston, VA, USA; McGraw-Hill: New York, NY, USA, 2009.

64. Read, J.; Whiteoak, D.; Hunter, R.N. The Shell Bitumen Handbook, 5th ed.; Thomas Telford: London, UK, 2003. 